\begin{tabular}{|c|c|c|}
\hline$\exists$ & $\begin{array}{c}\text { International Journal of Current Research } \\
\text { and Academic Review }\end{array}$ & \\
\hline $\begin{array}{l}\text { EXCELLENNT } \\
\text { PUBLISHERS }\end{array}$ & 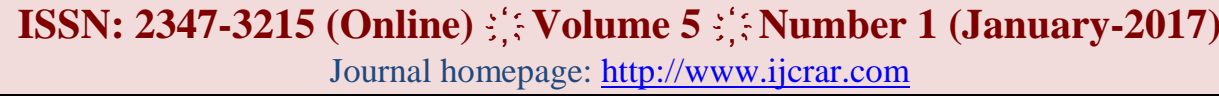 & \\
\hline
\end{tabular}

\title{
Donkeys Transport, Source of Livelihoods, Food Security and Traditional Knowledge, the Myths about Donkeys Usage: A Case of the Bolgatanga Municipality, Ghana
}

\author{
Maurice M. Braimah $^{1 *}$ and Avomah Oscar Mac Akampirige ${ }^{2}$ \\ ${ }^{1}$ School of Engineering, Department of Agricultural Engineering, Bolgatanga Polytechnic, Ghana \\ ${ }^{2}$ School of Applied Science \& Arts, Department of Liberal Studies, Bolgatanga Polytechnic, Ghana \\ *Corresponding author
}

\section{Abstract}

Even through donkeys have been extensively used by people in many areas in the world, their use has been synonymous with backwardness, under development and low status. In a qualitative and quantitative study of 120 households located within the Bolgatanga. Municipality, this study sought to provide an overview of the consequences of development for donkey use and management. The survey was done to assess donkey transport, sources of livelihoods, food security and traditional knowledge, and the myths about donkey usage in Bolgatanga. Municipality. Formal questionnaire and informal interviews were used to gather information from purposively sampled donkey owners. Descriptive statistics and linear regression were used to analyze the data. The donkey was a source of employment particularly for the rural dwellers and female-headed households in the transportation of goods. It also made a direct positive contribution of food security of many female-headed as well as low income households. Increasing net income from the donkey however resulted in a reduction in the expenditure made on food by most male-headed households while increasing the percentage of income saved. The study also tried to show how the use of donkey shad enabled these people to withstand some of the threats to their lives and livelihoods. The paper provides several examples of how these different uses ensured the survival of women and men in hostile environments and enables them to integrate into the social and economic processes from which they are often excluded. Government and NGOs, as a strategy to all eviate poverty may consider providing a donkey and cart to poor farming households and female-headed households in places with similar characteristics like Bolgatanga and its environs.
\end{abstract}

\section{Article Info}

Accepted: 28 December 2016

Available Online: 20 January 2017

\section{Keywords}

Attitude, Donkey-Cart, Farmers, Food Security, Households, Myths, Transport.

\section{Introduction}

The Upper East Region has the fifth highest human population density in Ghana but highest in northern Ghana (GSS, 2012). The main occupation of the people is farming. The population density coupled with extensive rocky outcrops in parts of the region leaves less land for agricultural activities (Adiisi, 2003). This is evidenced by the frequent food deficits reported in this region, and its attendant food insecurity (Amuah, 2004).

Livestock has been identified by many researchers and development workers as playing a major role in ensuring food security in northern Ghana (Reynolds, 1985; Millar et al., 1998; Thornton, 2010). The domestic poultry, 
sheep and goats have been identified as the food security animals because their sale provides cash for food, when household food crop barns are empty and for crop farm inputs for the next farm operations (Otchere et al., 1997). Animal traction may also be very strategic in the intensification of crop-livestock systems (Adiisi, 2003). According to Gina and Tadesse (2015), traction animals constituted a vital link between the house and the farm and they facilitated the creation of rural and urban economic development opportunities. The donkey has been found to be one of the most costeffective sources of transportation in peri- urban areas (Nengomasha et al., 2000). Animal traction can play an additional role of providing manure which is very important to ameliorate the soil. Ploughing with animals also causes less damage, compared to the tractor, due to the thin and already fragile topsoil characteristic of the region (Bobobee, 2000).

In northern Ghana, bullocks and bulls are the main animals used for ploughing. Efforts to improve food security through livestock improvement have focused on poultry, pig, sheep, goats and cattle (Otchere et al., 1997), giving little attention to the donkey. The presence of donkeys in the Bolgatanga area warrants a study on the value of their socio-economic contribution to the lives of the people. Also the strategic location of Bolgatanga as the regional capital

Donkeys are considered as beasts of burden in many developing countries (Crossley, 1991; Svendsen, 1991). Investigations of the role of donkeys in rural areas have received increasing attention from researchers and those in development over the last decade (e.g. Fielding and Pearson, 1991; Bakkoury and Prentis, 1994; Starkey, 1998). Despite the above, there is little quantitative information on their role as pack animals in marketing produce. Observations have shown that, in many periurban areas in Africa, draught animals can provide an important means of transporting goods and produce (Tesfahunegan, 1986). A donkey or other pack animals provide a means of transporting a range of products more rapidly to markets and in greater amounts than can be done on foot, but cheaper and more easily than relying on public transport or motor vehicles. It increases the range of distances over which produce from a farm can be sold. It is a door to door service, so perishable products such as vegetables (especially tomatoes in Ethiopia), milk, eggs, poultry, grain and animal fodder can arrive safely with less damage, stress or effort, than if they had to be transferred from one means of transport to another and back again. Tesfahunegan (1986) calculated that even with a single animal the potential cost reduction from substitution of pack for human carriage is of the order of 50\%. Howe and Garba (1997), in a study of subsistence farmers in Kaffecho Zone in Ethiopia found that pack animals offered the only realistic way of obtaining returns from agriculture above mere subsistence. Ownership of an animal in this area could significantly reduce total transport costs and increase both the returns to the farmer; and the range of distances over which it was economic to trade. In marketing crop products, high value products such as seeds offered better returns than the food staples such as maize and sorghum (Howe and Garba, 1997).

Pack animal transport is an enterprise that can be, and often is, undertaken by disadvantaged or displaced people (Sisay and Tilahun, 1997). Use of animals in transport has the potential to provide contractors with a steady income (Wilson, 1991; Gebreab, et al., 1997, Sisay and Tilahun, 1997). Several studies have shown that farmers with a cart or pack animal can get a higher price for their goods than those without access to animal transport (see review by Anderson and Dennis, 1994). Use of animals to move goods can help women in their daily activities. Women in peri-urban and rural areas have a heavy work burden. For example, in Ghana and Tanzania, a study of the transport needs of poorer sectors of the populations (Harrison and Howe, 1989) produced the following findings: the transport activities of a rural household in Tanzania occupy $2600 \mathrm{~h} / \mathrm{annum}$ and involve a load carrying effort of 100 tonne-kms. The figures for Ghana are $4800 \mathrm{~h} / \mathrm{annum}$ and 200 tonne-km. Women, on foot affect most of this transport. Most trips are undertaken to meet agricultural requirements, including marketing, and essential domestic needs (Harrison and Howe, 1989). Donkeys provide one of the best and most acceptable ways of reducing this workload in many different situations (Barwell and Dawson, 1993; Bryscon and Howe, 1993; Leyland, 1997).The main objective of the study was therefore to investigate into Donkey-Cart transportation as source of livelihood, food security and traditional knowledge, myths about donkey use in the Bolgatanga Municipality.

\section{Materials and Methods}

\section{Description of the study}

\section{Location}

The study was conducted in Bolgatanga, the Upper East regional capital of Ghana located between latitude $10^{\circ}$ 
47' 50" N and Longitude $0^{\circ} 52^{\prime} 40^{\prime \prime} \mathrm{W}$. (DMTDP, 2010). It covers an area of about $4,220 \mathrm{~km} 2$ which constitutes about $35.1 \%$ of the total land area of the Upper East Region. It is bounded to the north by Kassena Nankana District, on the west by Sisala District, on the south by West Mamprusi District and on the east by the Nabdam District as shown in Figure 1.0. It has a total population of about one hundred and thirty one thousand, five hundred and fifty $(131,550)$ of which $(62,783) 47.7 \%$ are male and $(68,767) 52.3 \%$ are female (PHC, 2010). The area falls under the Tropical Continental Climatic region which is influenced by two main air masses, namely the Southwest Monsoon and the Northeast Trade Winds. It is characterized by a single rainy season within a year, usually from May to October followed by prolonged dry season. The rainfall ranges from $110 \mathrm{~mm} /$ year to $800 \mathrm{~mm} /$ year with average evapotranspiration estimated to be about $890 \mathrm{~mm} /$ year but may reach $1000-1300$ $\mathrm{mm} /$ year in wet years and $650 \mathrm{~mm} /$ year in dry years. Between 1989 and 2005 rainfall has decreased from $1673.2 \mathrm{~mm}$ to $769.5 \mathrm{~mm} /$ year.

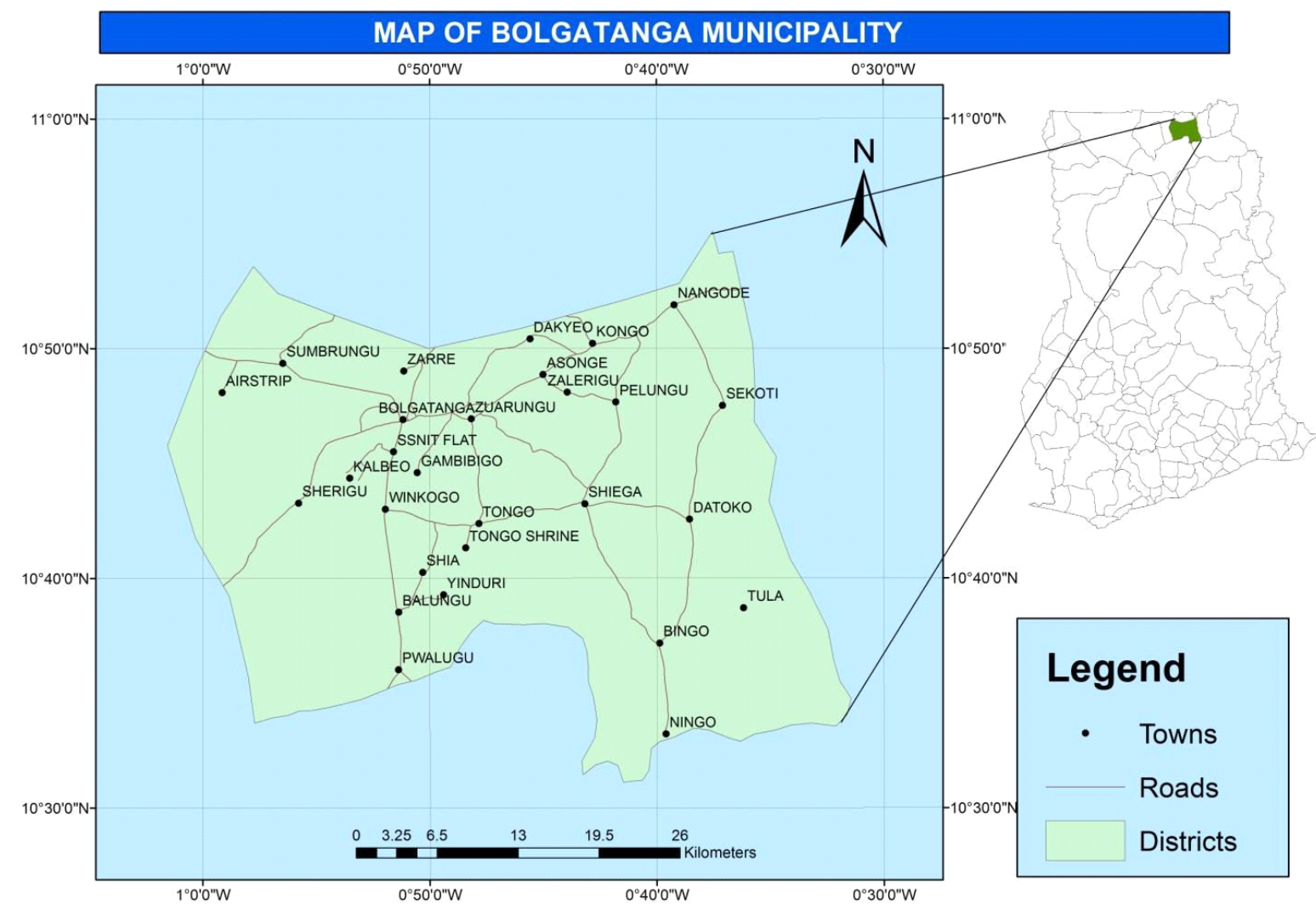

Mean monthly temperatures range from $42^{\circ} \mathrm{C}$ in March to about $26^{\circ} \mathrm{C}$ in August with the average daily temperature ranging from $28^{\circ} \mathrm{C}$ in July to $32^{\circ} \mathrm{C}$ in April (MOFA, 2006 or BAS, 2006). Within this climatic zone relative humilities are high during the rainy season (about 70 to $90 \%$ ) which may fall to about 20\% during the dry season. The vegetation is mainly of the Sahel Savannah type consisting of open Savannah with fire swept grassland separating deciduous trees (Dickson \& Benneh, 1988).

The vegetation of the Bolga municipal is characterized by savannah woodland and consists of deciduous widely fire and drought resistant trees of varying density with dispensed cover of perennial grasses and associated herbs. Through the activities of man, the woodland savannah has been reduced to an open pack land where only trees of economic value such as kapok, baobab, acacia, Shea nut and 'dawadawa' have been retained with time. These trees satisfy domestic requirement such as fuel wood. Timber for local housing construction, Cattle kraal, vegetable garden fence and material for handcart, in the dry season. Annual bushfires decimate the grasses and shrubs and as a result pasture for the livestock is largely destroyed. These bushfires also ravage the forest reserve in the district and render them distinguishable from the surrounding vegetation (DoF, 2001). 


\section{Research Design and Methodology}

Descriptive survey design (Knupfer and McLellan, 2001) was adopted in this study applying both qualitative and quantitative research methodologies. The study used structured close-ended questionnaires as the main instrument to collect data alongside with focused group discussions, key informant interviews and observation. These methods sought to provide an opportunity to have an in-depth knowledge of the research which hitherto was not clear. Empirical verification was done via observation on attitudes and behaviors of respondents (Anderson, 1971) to test the truth or otherwise of empirical statements. In all, three (3) focus group discussions were held with the various groups. It involved opinion leaders within selected communities, households, MOFA Staff, Farmer Based Organizations (FBO), etc. Others included in this interview were the Bolgatanga Municipal Assembly, staff of Irrigation Development Authority (IDA), some NGOs into Food Security issues and the staff from Environmental Protection Agency (EPA). This method sought to help these groups to freely express themselves concerning the subject. The researcher conducted a series of in-depth interviews with members of each of household during data collection. The interview with the participants focused on ten structured questions designed by the researcher. This was to ascertain and verify the other sources already employed to collect the information. Interpretation of the questionnaires to those who could not understand was done by the researcher and the appropriate responses ticked. A total of six thousand and twenty five $(6,025)$ male and female households' heads and other stakeholders aged 18 and above was obtained as the sample frame of the assessment survey. The sample size for the study was one hundred and twenty (120).

\section{Source of data and method of data collection}

Both primary and secondary data were used. Primary data were obtained from administered questionnaires and informal interviews. Secondary data were obtained from various sources of literature. In all a total of One hundred and Twenty donkey owners from 120 households in five communities were purposively sampled for interviews.

\section{Limitations of data}

Many respondents had difficulty in quantifying their farm outputs in monetary terms. Respondents also mostly relied on memory recall in stating how much income they earned annually from their donkeys.

\section{Data analysis}

Primary data was analyzed using descriptive statistics from SPSS software was used for the analysis of Data collected. Microsoft excel was used to determine the contribution of the donkey to household income and food security. Household expenditure on food per annum was regressed on household net income from the donkey per annum to measure the significance of income from the donkey on household food security. Total household annual income was also regressed on the total annual net income from the donkey in an attempt to assess the role the donkey played in promoting food and income security of the owner's household.

\section{Results and Discussions}

\section{Background information on respondents}

The average age of respondents who owned donkeys in the study area was 46 years, with the highest number of owners between the ages of 31 and 40 years. This was because, at this age many of the respondents were married and had established their own families and therefore needed to increase their income level and productivity to enable them live up to their responsibilities. From the ages of 61 and above, many of them were no longer able to cater adequately for the donkey and use it due to old age. Besides, their responsibility with regards to contributing to family sustenance would have also been alleviated by their children who would have become income earners as well.

Below the age of 30 however, the ownership of the donkey was low. This is perhaps because most people in this age category were unemployed and could not afford a donkey and cart, except for persons who had traveled to the south of Ghana to work for money or those from wealthy homes. Even though many of the people in the 21-30 age category did not own a donkey, they constituted the majority of the people who handled the donkey on behalf of their owners.

Average household size of respondents in the study area was 12 . About $58 \%$ of the respondents had a household size of $1-7$ people while $42 \%$ of the respondents had 8 or more persons per household. This shows a higher 
average household size than the 7 people indicated by the GSS (2012) in the population and housing census. In the opinion of respondents, household size did not have any effect on the ownership, however smaller households might be constrained in their ability to feed and water their donkeys.

On the level of Education, most of the respondents, 93 (58 \%) had no formal education with $28 \%$ having basic school education. Education has influence on perception and involvement, particularly in the decision making process and monitoring of activities regarding resource of an individual and how such an individual imbibes different dissenting opinions (Carr, 1994). The low level of formal education in the area means little formal training. This adds pressure on the natural resource in the area.

\section{The general overview of Donkey-Cart transportation as sources of livelihood over the past decade in Bolgatanga Municipality}

A general overview of donkey-cart transportation, with participants, over the past ten to twenty years revealed that due to the introduction of the Vea irrigation project in the area (over the past thirty years) has come to supplement the rain fed agriculture to ensure food security in the communities which eventually culminated to farm power derived from donkeys, especially those farmers situated along the project site. Over the period, dry season gardening for the production of vegetables, the cultivation of rice at the canals, fish farming, raising of livestock among other crop production were some of the reasons for improved food security situation and the need for transportation of farm produce by these animals in the study area. Moreover, the study uncovered that, improvement of education of the people in terms of agriculture production, the introduction of improved technology and the availability of farm inputs was keen to this development over the period. Finally, the youth in agriculture production had realized the importance of Donkey transportation and farm traction, which had a very significant impact on food security development and the transportation of farm produce in general during this period under review.

\section{Gender and ownership of donkey-carts}

The study showed that the type of transport system that majority of the people of Bolgatanga Municipality operate on were Donkey-cart transport system, bullock transport system and motor king transport system (Table 4.1). Respondents were asked to indicate whether they owned any form of transport system for carting farm produce and the type of transport system they operated on. About three-quarters (75\%) of the people interviewed who indicated owning donkey-carts were men while women ownership of donkey-cart accounted for approximately $25 \%$ using it for transport system and livelihoods in Bolgatanga Municipality. The $25 \%$ own by women were those left over by their late husbands or any male relative. Though ownership of donkeys by people of all sexes is common in many societies, in Bolgatanga Municipality, they are owned, used and controlled by men. The interview session confirmed that even women who owned donkey-cart cannot openly sell them without consulting a man. This is similar to studies by Mutharia, (1995) of several communities in Sahelian countries that the ownership of donkeys is almost entirely by men and that, among the Maasai, for instance, though women had access to the use of donkeys, a woman could sell a donkey without a man's permission.

However, the responses from table 4.1 shows that though men owned donkeys, no male used donkey-cart or bullock-transport system for carting farm produce form the farm by themselves. Only $8.3 \%$ of the males owned motor king that was used for carting farm produce. However, all $25 \%$ of the women who owned donkey-cart transport system used them for carting farm produce. No female owned bullock transport system or motor king transport system used for carting farm produce. When owners of donkey carts were interviewed for the reasons for having or keeping donkeys in the district, they gave the following reasons for preferring donkeys to other animals; it is possible to plough with a single donkey than other animals; that donkeys worked faster than other animals and are easier to train; that donkeys are harder than other animals, in that they tolerate drought better, are less susceptible to diseases and are in good condition at the end of the dry season and did not need supplementary feeding before they begin ploughing. The low value of donkeys also makes them less susceptible to theft. That women could use donkeys easily and access to donkeys is to show wealth. The low price of donkeys is in most part related to the fact that they are not perceived as multi-use animals. For instance donkeys are not usually considered in the payment of bride price and even donkey money is not used for dowry (else the wife will become a fool like the donkey as the people believe). The lower cost of donkeys makes them more affordable 
to the people of Bolgatanga Municipality. Price is however, not the only determining factor for the increased use of donkeys in Bolgatanga Municipality.

At Sirigu, specifically, it was revealed that, women used donkey-cart transport system to support them carry their goods to market but their husbands or male children used them for ploughing and later sell them for money.

Table 4.2 indicated that, $41.7 \%$ of respondents acquired the donkeys through individual effort and inheritance. Only $6.6 \%$ responded acquiring donkeys through restocking agent. Those who acquired donkeys through friends or relations were $11 \%$. Nobody in the study area acquired donkeys through dowry.

\section{Traditional knowledge and Myths about Donkey and its Uses}

Almost all traditional users interviewed confirmed they had some knowledge about the utilization and management of donkeys they possessed. The Bolgatanga Municipality people had a range of traditional equipment that they used with donkeys for fetching water, carrying household goods, carrying sick people to hospitals and many others. Traditional communities also had certain beliefs relating to donkeys. Some indigenous people living in the community believed, for instance that, those donkeys must be exchanged, not sold, because selling a donkey for money; especially women, will bring misfortune to the seller. They also believed that to kill a donkey, it must not see the killer at the time of killing. Additionally, when killing a donkey, they covered its face with a sack to prevent it from seeing the killers or else its ghost will hunt all of them (the killers). These Local sayings reflect local communities' attitudes towards donkeys. In Sumbrungu and other surrounding communities, they have the saying that, "Donkeys reward you with a kick since it cannot talk". Sometimes, the myths associated with donkeys prevent their use for other things such as dowry or as gift or a token of appreciation to people. For example, overworking a donkey in a field will make the donkey cry and if a donkey cries in a field the crops will fail. This and others made people to use them with care.

Table 4.3 revealed that about $74.8 \%$ of the respondents said "Yes" to the item on using donkey-cart for transport system in their community, while $25.2 \%$ said "No" to the item. The most frequently used community of donkey cart for transport system was in Zaare,
Sirigu, Zuarungu, Sumbrungu and Yekini respectively. The Yekini community was the least in terms of donkey-cart use as a means of transport for livelihood.

\section{Donkeys for transport}

The use of donkeys for transport in Africa dates back to historic times (Fielding, 1988). This is in contrast to the situation in many African farming systems, where farmers have only recently started to use donkeys for cultivation because of changes in land-use patterns, agro-ecological conditions and labour availability. Packing is one of the most ancient forms of transport that preceded even the invention of the wheel; that it has survived to the present day emphasises its value (Fielding, 1988).

The use of donkeys as pack animals or for pulling a cart has enabled small-scale farmers to participate in the market economy of the municipality. Donkeys have reduced the domestic transport burden of rural women and have created employment and income-generating opportunities for many people. The Maasai community in Kenya uses donkeys for fetching water, for household shifting (during migration), for carrying the sick to hospital, for carrying sick calves, for transporting, shopping and for pulling fencing materials needed for constructing bomas (Mutharia, 1995). In Botswana, donkeys are used for transporting people and goods, for transporting sand for building houses and for fetching water and firewood (Aganga et al., 1994). In the more remote mountainous areas of Lesotho, donkeys are important for transporting grain to the mills (Moorosi, personal communication).

In Ethiopia, donkeys are a major mode of transport. They transport at least 12 different commodities including vital food supplies. During recent wars, donkeys kept guerrilla armies supplied with food, guns and ammunition. Some rural Ethiopians recall that in famines of the past they only survived by someone bringing in food on donkeys (Marshall and Zahra Ali, 2000). The role of donkeys in assisting refugees and guerrilla fighters is commemorated in northern Ethiopia. In Cairo and other Egyptian cities, Zabbalin communities use donkeys for rubbish collection (Salah Fahmy, 2000).

\section{Socio-economic development issues of Donkeys}

To measure the Socio-economic development issues of Donkeys transport system, respondents were asked to 
indicate the extent to which it was helpful to the people in the district and the owners. There is an association between education of people and their donkey cart transport system. The study concluded that the higher the education level, the better they performed (up to a certain point) in generating income through farming activities and other ventures. For example, people with educational background used modern technologies in farming activities whereas those without educational background used only traditional methods in farming. However, those with higher education turned to do only backyard garden farming. Some of the people in the study area ploughed up to 8 and above acres of land. A few of them said they were able to plant without using donkey draught animal.

During the interview with indigenous people in the study area, it was asserted that the donkey meat is the most clean and tastiest one on earth. They added that it is the strongest animal and that is why they used them for carting. Donkey cart use in the district had helped a lot in socio-economic growth of the people and had helped to improve education levels, health care and social provision. But large numbers of people in the study area had not benefited from this animal power. It was later revealed that, the people of Bolgatanga Municipality were not aware of the socio-economic development of donkeys. What has become increasingly obvious, as governments, multilateral and bilateral agencies pursue 'development' is that, economic growth does not eliminate poverty but alert people to work hard.

\section{Attitudes of people towards donkey cart possession and policies}

Despite the apparent advantages and importance of using donkeys to transport goods, recognized by the public who are direct beneficiaries of the service, government planners and officials in general tend to regard it as an inferior occupation and are not keen to support these activities, particularly in urban areas, unless they can be convinced of the economic importance. The perceived adverse effects on traffic congestion of donkeys entering and leaving towns, their nuisance value and large concentrations at market places, also hardens official attitudes against donkey use in the peri-urban fringes.

In future, this is an issue that is unlikely to be confined to Bolgatanga Municipality but may spread to other parts of peri-urban Africa where road traffic is increasing, but donkeys are currently bringing goods into and out of towns, both by pack and cart. Table 4.4 shows the raw counts of the responses to the liker scale on attitude towards donkey cart possession and policies.

The results from table 4.4 shows that farmers had positive attitude towards donkey cart possession policies. About $62.6 \%$ responded positively to all the attitudinal dimensions measured. While a total of $27.4 \%$ responded negatively to the items. The highest positive response was in 'Interest in donkey cart activities (76.9\%). Again about $76.2 \%$ indicated a positive response to routine maintenance. The least positive response was in the dimension of hiring of donkeys. The table shows that the people of Bolgatanga Municipality had positive attitude towards the use of donkey cart transport system and that had, to some greater extent, positive impact on the people.

\section{Environmental issues}

In some urban areas, donkeys are regarded as an environmental hazard. However, people of the study area opined that donkeys were environmentally friendly animals. Respondents indicated that when donkeys are housed well, they did not smell or pollute the environment with faeces. Rather the manure is collected and sold as fuel to low income families in the village. This is an extreme case. However, the problems of environmental pollution when large concentrations of animal congregate cannot be discounted. Increased use of donkeys in transport would add to this problem. On the positive side, collection of the manure for fuel reduces demand for firewood although increased availability of donkeys to transport firewood might be detrimental to forests.

\section{Donkey health and welfare}

The study revealed that donkeys were the healthiest animals; donkeys did not often fall sick like other animals. On the question of feeding of donkeys, some respondent said, small boys who dropped out of school were hired to guide the animals to the forest to feed (them with) grasses. Others put them at one place but looked for grasses and other food materials to feed them. Getting source of water was not a problem because of the availability of the dams in the selected communities. Some fed their donkeys with salt and others did not. During the dry season, donkeys were fed with dry grass and that still made them fit. 


\section{Donkey transport in agriculture production}

The study result in the focused group discussion indicated that the impact of Donkey-cart transport system on the livelihood of the farmers in the Bolgatanga Municipality in agriculture production was above average. The people interviewed stated that donkeys were used in agricultural production, mainly to transport manure to the fields and the harvest from the fields to the homes and to the market centres. These transport functions were becoming critical as land is more intensively cultivated and families begin to depend on income from marketing cash crops. The study on the impact of donkeys-cart transport in Bolgatanga Municipality indicated that the use of donkey-carts was an essential component of the farming system. The Bolgatanga Municipality is a highly productive agricultural area and the agricultural systems practiced by the farmers required a great deal of animal power for transporting of farm produce.

Most (91.7\%) households in Bolgatanga Municipality depended on donkey carts for the transport of items to the market; farm produce and many others. Donkey carts were used by $58.3 \%$ of the households for marketing crops sold in local markets and over $16.7 \%$ of the households for the marketing of crops which were sold in more distant markets, while $25 \%$ of other services for Donkey cart transport system on the livelihood of the people of Bolgatanga Municipality in agriculture production were recorded.

During the dry seasons, farm animal food is scarce and the owners of livestock have to move from place to place to find it. In such periods, ownership of donkey cart transport enables the livestock farmer to move longer distances to carry the available food in reasonable amounts, all by means of donkey cart transportation.

\section{Reasons for keeping the donkey}

The main reason donkeys were kept in the Bolgatanga area was for transportation ( $91 \%$ of respondents) of household resources such as water, building materials, farm inputs and farm produce that might have otherwise been carried by women and children over long distances. According to Valette (2014), donkeys were used to bring in feed for the other livestock species and also carry sick animals to the veterinary clinic. Fielding and Krause (1998) remarked that pack donkeys alleviated the work of women farmers by carting farm produce over long distances. Manure from the donkey was also used by farmers to improve the fertility of the soil on their farms for increased crop production. A few respondents also indicated that they harnessed their donkeys for ploughing since they could not afford oxen but at the same time needed to take advantage of early rains to obtain good harvest. In Ghana where refuse management is a problem, donkeys can be used to perform the task of refuse collection. Donkeys were also kept for their meat in the municipality.

\section{Other costs involved in keeping and using the donkey}

The costs incurred on the donkey included the harness of the donkey, repairs of cart, feeding and watering, housing and healthcare. No cost was incurred in the training of the donkey because the respondents did the training themselves. Feeding accounted for about $41 \%$ of the other costs, followed by repairs of cart $(27 \%)$. Health and harness were $13 \%$ each while housing formed $6 \%$ of these costs per annum. Mean cost of maintaining the donkey and cart per annum was estimated at US\$37.57. Feed was quite expensive in Ethiopia (US\$100.00) (Admassu and Shiferaw, 2011) and India (US\$1,830.00) (Zaman et al., 2014), and interventions are needed in Ghana to keep feed cost low. It was realized that majority of the respondents prepared their own harnesses from local materials and about $95 \%$ of them did not provide housing facilities for their donkeys but rather tied them in the yard or outside the house exposing them to the vagaries of the weather. This notwithstanding, disease incidence of these donkeys was observed to be low. Compared to cattle Pandey and Eysker (1991) reported that donkeys were less likely to succumb to diseases. Also, they are better adapted to dry conditions and subsist on less feed (Gina and Tadesse, 2015). According to Geiger and Hovorka (2015), perhaps because of their hardness, donkeys suffer various abuses at the hands of people particularly children who handle them and this raises a number of animal welfare concerns.

A donkey health as in Botswana revealed that $69 \%$ of the surveyed population of donkeys exhibited a sad demeanour and a significant correlation was detected between scar prevalence on the donkey and disinterest in its handler (Geiger and Hovorka, 2015). Canacoo and Avornyo (1998) estimated the time donkeys spent grazing in the dry season to be about $80 \%$ and it is doubtful if donkeys used for work actually get enough time to rest or feed. 


\section{Household annual expenditure on food}

The mean of household annual expenditure on food for the 120 respondents was US\$855.49. Of this amount, they spent US\$362.24 on tuo zaafi (thick porridge made from maize, sorghum or millet flour), US\$184.20 on rice and stew, US\$185.29 on rice and beans stew, US\$62.06 on porridge, US\$28.37 on banku (thick porridge prepared with maize and cassava dough), US\$15.00 on fufu (pounded boiled yam or cassava and plantain), US\$5.00 on kenkey (thick porridge main staple of the people of the Upper East Region was tuo zaafi.

\section{Households mean annual income from livelihood sources}

The mean annual income of the 120 households was US $\$ 1,160.87$. Of this amount, the donkey contributed a mean of US $\$ 217.78$, constituting about $19 \%$ of the mean annual income of the household. This placed the donkey as the second largest contributor after crops to household income for the respondents in the study area. Next in a decreasing order was animal rearing, salary, remittances from relatives and corn mill operation as major sources of income for the households (Table 3). According to Admassu and Shiferaw (2011), equines in Ethiopia contributed about $14 \%$ to total household income, and their contribution appeared to be higher than the contribution from other livestock species. They estimated an annual income of about US\$750.00 from equines compared to the low value of US\$217.78 reported in this study. Warboys et al. (2014) recorded a daily income of US\$10 from equine services in Honduras.

\section{Contribution to food security in female- headed households}

When the 120 households were separated into male and female-headed households, the relationship between net income from the donkey and the amount spent on food per annum in female-headed households was positive though not statistically significant:

$\mathrm{y}=0.48^{\mathrm{N} . S}( \pm 0.56) \chi+735.93^{* * *}( \pm 131.74)$

where:

$\mathrm{y}=$ expenditure on food,

$\chi=$ net income from donkey,

N.S. = not significant, and

$* * *=\mathrm{P}<0.001$
In the female-headed households, the equation was suggesting an increase in the amount of money spent on food with increasing net income from the donkey. The equation was also suggesting that the food security levels of the female-headed households varied widely. The high error value $( \pm 0.56)$ associated with the regression coefficient describes the situation where majority but not all the female-headed households used a significant amount of their net incomes from the donkey for household food consumption. For the female-headed households therefore, there was the tendency to use their net income from the donkey on the purchase of food for the house. This implies majority of the female-headed households probably used the donkey as a food security animal. For the 25 female-headed households, the amount spent on food per year when net income from the donkey was zero, was about US\$735.93 compared to an estimated US $\$ 855.49$ for the one hundred households surveyed. A higher proportion of the female- headed households might therefore be vulnerable, especially without the donkey. According to Gina and Tadesse (2015), work animals were a resource for sustainable food production and enhanced food security. Genderresponsive climate change interventions may consider the promotion of donkeys for poor female-headed households (Valette, 2014).

\section{Contribution to food security in male-headed households}

Concerning the 75 male-headed households that were included in the survey, the relationship between their net income from donkey use and total expenditure on food per annum was negative and given by;

$y=-0.69^{\text {N.S }}( \pm 1.74) x+983.80^{* * *}( \pm 277.26)$,

where:

$\mathrm{y}=$ total annual expenditure on food,

$\chi=$ net income from donkey use,

N.S. = not significant, and

$* * *=\mathrm{P}<0.001$

In the male-headed households, the estimated average amount spent on food per household per year was US\$983.80 when net income from the donkey was zero. With increasing incomes from the donkey, the majority of male-headed households appeared to reduce their annual expenditure on food. Only few male-headed households increased expenditure on food with increasing net income from the donkey. Many of the male-headed households by their own estimation were 
food secure even without income from the donkey. The male-headed households had a greater tendency to save on food while they were realizing increased net returns from their donkey enterprise. It appeared that the increasing net income from the donkey was associated with a decision to make more savings to invest in some other property. It was as though the donkey substituted for human labour for food production or earning income, and their presence resulted in a decrease in the number of people to be fed in a household or an increase in food production. The observations of Mrema (1994) were indicating that families with a donkey and cart benefited from early planting and more food harvest than those without this resource.

\section{Contribution of the donkey to house hold total annual income}

The contribution of the net income from the donkey to household total annual income was described by the equation:

$\mathrm{y}=0.58^{\mathrm{N} . S}( \pm 0.65) \chi+1,138.84^{* * *}( \pm 103.69)$, where:

$\mathrm{y}=$ household total annual income,

$\chi=$ household annual net income from

donkey use,

$\mathrm{N} . \mathrm{S}=$ not significant, and

$* * *=\mathrm{P}<0.005$

There was a positive, albeit not statistically significant relationship between net income from the donkey and annual total income. When net income from the donkey was zero, the total annual income per household was generally still significant (US\$1,138.84). The majority of donkey owners in Bolgatanga Municipality were therefore probably already food secure because the total annual income per household (US\$1,138.84) exceeded the estimated annual expenditure on food per household (US\$855.49). While the contribution of the net income from the donkey might be significant for some households, it was not significant for all households surveyed. This observation is supported by the high variance (standard error $=0.65$ ) associated with the regression coefficient.

Table 4.1. Percentages of Ownership of Donkey-cart and type of transport system operate on by sex

\begin{tabular}{|l|c|c|c|c|c|}
\hline Ownership of Donkey- Cart & \multicolumn{5}{|c|}{ Type of Transport System } \\
\cline { 2 - 6 } & & $\begin{array}{l}\text { Donkey } \\
\text { cart } \\
\text { transport } \\
\text { system }\end{array}$ & $\begin{array}{l}\text { Bullock } \\
\text { Transport } \\
\text { System }\end{array}$ & $\begin{array}{l}\text { Motor } \\
\text { King } \\
\text { Transport } \\
\text { System }\end{array}$ & Total \\
\hline \multirow{2}{*}{$\begin{array}{l}\text { Male: Own any form of } \\
\text { transport system }\end{array}$} & Yes & 58.4 & 8.3 & 0 & $\mathbf{6 6 . 7}$ \\
\cline { 2 - 6 } & No & 0 & 0 & 8.3 & $\mathbf{8 . 3}$ \\
\cline { 2 - 6 } & Total & 58.4 & 8.3 & 8.3 & $\mathbf{7 5}$ \\
\hline \multirow{2}{*}{$\begin{array}{l}\text { Female: Own any form of } \\
\text { transport system }\end{array}$} & Yes & 25 & 0 & 0 & $\mathbf{2 5}$ \\
\cline { 2 - 6 } & No & 0 & 0 & 0 & $\mathbf{0}$ \\
\cline { 2 - 6 } & Total & 25 & 0 & 0 & $\mathbf{2 5}$ \\
\hline
\end{tabular}

Table 4.2. Responses to how Donkeys are acquired for Transportation of Farm Produce

\begin{tabular}{|l|c|}
\hline Source of acquisition & Percent \\
\hline Individual Efforts & 41.7 \\
\hline Inheritance & 41.7 \\
\hline Restocking Agent & 6.6 \\
\hline Friends/Relations & 11.0 \\
\hline Dowry & 0.0 \\
\hline Others & 0.0 \\
\hline Total & $\mathbf{1 0 0 . 0}$ \\
\hline
\end{tabular}


Table 4.3. Responses to those house donkey-cart as transport system by communities

\begin{tabular}{|l|l|l|c|}
\hline \multirow{2}{*}{ Community } & \multicolumn{3}{|l|}{$\begin{array}{l}\text { Using Donkey- Cart Transport } \\
\text { System for Livelihood }\end{array}$} \\
\cline { 2 - 4 } & Yes & No & Total \\
\hline Sumbrungu & 12.3 & 5.7 & $\mathbf{1 8}$ \\
\hline Yekini & 10.4 & 6.2 & $\mathbf{1 6 . 6}$ \\
\hline Zaare & 18.9 & 3 & $\mathbf{2 1 . 9}$ \\
\hline Sirigu & 17.4 & 2.8 & $\mathbf{2 0 . 2}$ \\
\hline Zuarungu & 15.8 & 7.5 & $\mathbf{2 3 . 3}$ \\
\hline Total & $\mathbf{7 4 . 8}$ & $\mathbf{2 5 . 2}$ & $\mathbf{1 0 0 . 0}$ \\
\hline
\end{tabular}

Table 4.4. Percentages of people responding to the various Items constituting attitude towards donkey cart possession and policies

\begin{tabular}{|l|c|c|}
\hline \multicolumn{1}{|c|}{ Items } & Positive & Negative \\
\hline Routine Maintenance on Donkey Cart & 76.2 & 23.8 \\
\hline Veterinary Services & 63.1 & 36.9 \\
\hline Interest in Training Donkey Cart & 76.9 & 23.1 \\
\hline Hiring of Donkey Cart & 55.6 & 44.4 \\
\hline Extension Officers and Veterinary Officials & 61.0 & 39.0 \\
\hline All & $\mathbf{6 2 . 6}$ & $\mathbf{2 7 . 4}$ \\
\hline
\end{tabular}

Table 4.5. Percentages of people responding to the various Items about Donkey transport in agriculture production

\begin{tabular}{|l|c|}
\hline \multicolumn{1}{|c|}{ ITEMS } & PERCENT \\
\hline Sold in more Distant Market & 16.7 \\
\hline Sold in Local Market & 58.3 \\
\hline Things to market & 91.7 \\
\hline Other Services & 25.0 \\
\hline Total & $\mathbf{1 0 0}$ \\
\hline
\end{tabular}

\section{Conclusion}

Donkeys have not been considered a significant component of the development process. For many of the institution promoting 'development', the use of donkeys have been considered an indicator of backwardness and underdevelopment Traditional attitudes to donkeys have also been quite negative and in some instances have inhibited the spread of donkey use. This attitude has led to a loss in the traditional knowledge relating to donkeys and to a lack of investment in the research and development of donkey issues. Field observations however, indicate that this may be changing. In parts of Ghana, farmers observed that in periods of significant food insecurity, donkeys were more important than oxen. In one area, people are now even considering donkeys as appropriate for bride price (marshal et al., 1997).

Donkeys are owned and used by large numbers of people engaged in small scale agriculture, by small - scale transporters and, in some areas, by women. Ownership and access is made possible by the relatively low value of donkeys and by their perceived low status. Increasing recognition of the importance of donkeys (particularly their ability to withstand drought and their role in transport) is resulting in a spontaneous diffusion of donkeys to 'new' areas. In many communities, households without donkeys are able to access them through sharing and hiring arrangements.

Donkeys are used in a variety of activities. Smallholder farmers use donkeys to cultivate their land, coping with labour shortages and loss of other livestock due to drought. By using donkeys in agriculture and transport, farmers have increased their productive potential and expanded their marketing options. Donkeys have also provided employment for many people who hire out donkeys or use donkey carts on a commercial basis for a transport service. 
The use of donkeys has enabled women to overcome the cultural barriers to the use of work animals and to mitigate some of the additional burdens that intensification of cultivation and shortages of labour have imposed on them. In most societies where donkeys are easily accessed by women they find it easier to work with them and have benefited from their use in farming, and in relieving women's domestic transport burden. The use of donkeys has also helped women make use of new income-generating opportunities and contributed towards changing gender power relations. Gender inequalities that restrict women's ability to make use of existing systems of trade to acquire donkeys, carts and equipment can be overcome by alternative credit arrangements.

The above discussion indicates that donkeys have been made 'invisible' by the formal institutions of development. However, women and men marginalized by the development process are using donkeys as a resource to ensure their survival in a hostile environment. In some cases donkeys allow disadvantaged people to reestablish links with the social and economic processes from which they have been excluded.

The main objective of development must be the improvement of the lives and living standards of the people who comprise society. This must be the alternative to the model that puts economic growth and 'modernization' of nations as its goal. For development professionals subscribing to this alternative, the challenge is to recognize donkey use and management as an appropriate and affordable technology for farmers with minimal resources.

\section{References}

Admassu, B. and Shiferaw, Y. 2011. Donkeys, horses and mules - their contribution to people's livelihoods in Ethiopia. The Brooke, Addis Ababa, Ethiopia 72 pp.

Adiisi, J. A. 2003. Assessing the impact and constraints of draught animals: a case study in the Bongo District in the Upper East Region. B.Sc. Thesis, University for Development Studies, Tamale, Ghana Pp 48-49.

Amual, D. 2004. Programme for Strengthening Community Organization Development and Development (POSCOM) with communities in the Kassena-Nankana District Assembly. A report prepared by POSCOM, P. O. Box 207, Bolgatanga, Upper East Region, Ghana 22 pp.
Aganga, A.A., Tsopito, C.M. \& Seabo. D. 1994. Donkey Power in Rural Transportation: A Botswana Case Study. Appropriate Technol. J., 21(3): 32-33. Intermediate Technology Publications. London. UK.

Bakkoury, M \& Prentis, RA. eds) 1994. Working Equines, Proceedings of the Second International Colloquium, April, 20-22, Rabat, Morocco, Actes Editions, Rabat.

Bryceson, DF. ed.. 1995. Women Wielding the Hoe. Lessons from Rural Africa for Feminist Theory and Development Practice. Oxford: Berg.

Bryceson, DF \& Howe, J. 1993. Rural Household Transport in Africa: Reducing the Burdenon Women? Africa Studies Centre Working Papers, Vol 15, Leiden, The Netherlands.

Canacoo, E. A. and Avornyo, F. K. 1998.

Daytime activities of donkeys at range in the coastal savanna of Ghana. Appl. Animal Behaviour Sci., 60: 229-234.

Crossley, P. 1991. Transport for Rural Development in Ethiopia. In: Donkeys, Mules and Horses in Tropical Agricultural Development (eds D. Fielding and RA. Pearson), pp 48-61, Centre for Tropical Veterinary Medicine and School of Agriculture, University of Edinburgh. Edinburgh, 20 pp. ISBN 0-907146-11-2.

Fielding, D. 1988. Pack Transport with Donkeys. Appropriate Technology Journal 15 (3) 11-13. Intermediate Technology Publications. London. UK.

Fielding, D. and Krause, P. 1998. Donkeys; The Tropical Agriculturist. Center for Tropical Veterinary Medicine, University of Edinburgh. Macmillan Education Ltd. London. Pp 7-12

Gebreab Fesesha, Wold, A. G., Kelemu, F., Ebro, A. and Yilma, K. 1997. An overview of donkey utilization and management in Ethiopia. Paper given at the Animal Traction Network of Eastern and Southern Africa (ATNESA) Workshop "Improving donkey utilisation and management" 5-

Geiger, M. and Hovorka, A.J. 2015. Using physical and emotional parameters to assess donkey welfare in Botswana. J. British Vet. Assoc., 2: 1.

Ghana Statistical Service (GSS). 2012. Population and housing census. Summary report of final results. Sakoa Press Ltd 105 pp

Gina, T. G and Tadesse, B. A. 2015. The role of working animals toward livelihoods and food security in selected districts of Fafan Zone, Somali Region, Ethiopia. Adv. Life Sci. Technol., 33: 88 - 94. 
Millar, D., Karbo, N, Bruce, J., and Otchere, E. O. 1998. Group formation and West African Shorthorn Cattle development among the Konkombas and Chokosi of the Saboba-Chereponi District of the Northern Region. Technical Report. Animal Research Institute, Nyankpala, Ghana.

Mutharia, L. 1995. Oloyiankalani Group Ranck: A participatory assessment of pastoral resources and their utilisation in selected areas of Kajiado
District. Intermediate Technology Kenya. P.O.Box 39493. Nairobi.

Pearson, R.A. and Ouassat, M. 2000. A guide to live weight estimation and body condition scoring of donkeys. Centre for Tropical Veterinary Medicine, University.

Tesfahunegan, M. 1986. Rural transport systems in Ethiopia. In: Towards a food and nutrition strategy for Ethiopia pp 456-482, Alemaya University of Agriculture, Ethiopia.

\section{How to cite this article:}

Maurice M. Braimah and Avomah Oscar Mac Akampirige. 2017. Donkeys Transport, Source of Livelihoods, Food Security and Traditional Knowledge, the Myths about Donkeys Usage: A Case of the Bolgatanga Municipality, Ghana. Int.J.Curr.Res.Aca.Rev. 5(1), 1-13. doi: http://dx.doi.org/10.20546/ijcrar.2017.501.001 